\title{
An Archaeological Evaluation of Three Prehistoric Sites Upper Cibolo Creek Watershed, Kendall County, Southern Central Texas
}

Fred Valdez Jr. Department of Anthropology, The University of Texas at Austin

A. Joachim McGraw

Follow this and additional works at: https://scholarworks.sfasu.edu/ita

Part of the American Material Culture Commons, Archaeological Anthropology Commons, Environmental Studies Commons, Other American Studies Commons, Other Arts and Humanities Commons, Other History of Art, Architecture, and Archaeology Commons, and the United States History Commons

Tell us how this article helped you.

This Article is brought to you for free and open access by the Center for Regional Heritage Research at SFA ScholarWorks. It has been accepted for inclusion in Index of Texas Archaeology: Open Access Gray Literature from the Lone Star State by an authorized editor of SFA ScholarWorks. For more information, please contact cdsscholarworks@sfasu.edu. 


\section{An Archaeological Evaluation of Three Prehistoric Sites Upper Cibolo Creek Watershed, Kendall County, Southern Central Texas}

\section{Creative Commons License}

\section{(c) (1) \&}

This work is licensed under a Creative Commons Attribution-NonCommercial 4.0 International License 


\title{
An Archaeological Evaluation of Three Prehistoric Sites Upper Cibolo Creek Matershed, Hendall County, South Central Texas
}

\author{
FRED V ALDEZ, JR. AND A, JOACHIM MCGRAW
}

Center for Archaeological Research The University of Texas At San Antonio

Archaeological Survey Report, No. 44

1977 


\section{AN ARCHAEOLOGICAL EVALUATION OF THREE PREHISTORIC SITES \\ UPPER CIBOLO CREEK WATERSHED, \\ KENDALL COUNTY, SOUTH CENTRAL TEXAS}

Fred Valdez, Jr. and A. Joachim McGraw

Center for Archaeological Research The University of Texas at San Antonio Archaeological Survey Report, No. 44

1977 
TABLE OF CONTENTS

Page

List of Figures ..................... i i

List of Tables ..................... i

Acknowledgments .................... i i

Introduction .................... 1

Previous Archaeological Research ......... 1

Field Investigations .............. 1

Results of Field Investigations . . . . . . . . 2

41 KE $46 \ldots \ldots \ldots 2$

41 KE $54 \ldots \ldots \ldots \ldots . \ldots \ldots$

41 KE $57 \ldots \ldots \ldots . \ldots . \ldots 9 . \ldots$

Summary and Recommendations............ 14

References Cited ................ 15 


\section{LIST OF FIGURES}

Figure

Page

1. Area Map Showing Locations of Sites $41 \mathrm{KE} \mathrm{46,}$

41 KE 54 and 41 KE 57............ 3

2. $41 \mathrm{KE} 46^{\circ} \ldots \ldots \ldots . \ldots . \ldots 4$

3. Lithic Artifacts ......... 5

4. $41 \mathrm{KE} 54 \ldots \ldots . \ldots . \ldots$

5. $41 \mathrm{KE} 57 \ldots \ldots . \ldots 10$

6. $41 \mathrm{KE} 57 \ldots \ldots \ldots \ldots$

7. $41 \mathrm{KE} 57 \ldots \ldots \ldots \ldots . \ldots . \ldots . \ldots . \ldots$

\section{LIST OF TABLES}

Table

Page

1. Provenience of Collected Materials from $47 \mathrm{KE} 46 \ldots \ldots 6 . \ldots . . \ldots 6$

2. Provenience of Collected Materials from 41 KE $57 \ldots \ldots . \ldots 13$ 


\section{ACKNOWLEDGMENTS}

The authors wish to express their gratitude to several individuals for their aid and cooperation during this project: Mr. Harold Coffee of the Soil Conservation Service in Boerne, Texas; Mr. Waynne Cox (Technical Staff Assistant) of the Center for Archaeological Research, The University of Texas at San Antonio, for his long hours of excavation; and volunteers Mrs. Kathy Gonzalez and Mr. Roger Hemion.

A special word of thanks is extended to Mr. Julius Gompert, owner of the property on which sites $41 \mathrm{KE} 46$ and $41 \mathrm{KE} 54$ are located, for his friendly acceptance of our crews and his perceptive observations concerning sites in the area.

We also wish to thank $\mathrm{Dr}$. Thomas R. Hester, Director of the Center for Archaeological Research, and $/$ r. Jack D. Eaton, Assistant Director, for their guidance, advice and suggestions on field methods and the interpretation of the excavated data.

Special thanks go to Mrs. Joan F. Valdez for the typing of the first draft of this report, to Jeanette Burch who typed the manuscript for publication and to Elizabeth Branch, for her work in editing the report. 
During the summer of 1977, personnel from the Center for Archaeological Research, The University of Texas at San Antonio (UTSA), conducted archaeological test excavations at three sites along Frederick Creek in Kendall County, Texas. These sites were located in areas proposed for modification by the construction of Floodwater Retarding Structure \#3 in the Upper Cibolo creek watershed. The field work was conducted under a contract between the Center for Archaeological Research and the United States Department of Agriculture Soil Conservation Service (Purchase Order No. 40-7442-7-1212).

An initial survey of the area had been conducted in February 1975, and resulted in the documentation of two historic and 17 prehistoric sites (Bass and Hester 1975). Three prehistoric sites, 41 KE 46, 41 KE 54 and 41 KE 57, were recommended for testing to evaluate their importance.

To more clearly define the archaeological potential of these three sites, the investigations had two major objectives: (1) to accurately determine the horizontal and vertical extent of the cultural deposits; and (2) to evaluate these archaeological resources in terms of possible nomination to the National Register of Historic Places.

\section{PREVIOUS ARCHAEOLOGICAL RESEARCH}

Although Kenda11 County contains a portion of the upper Guadalupe River watershed and possesses attractive natural resources, less than 100 archaeological sites have been recorded (as compared to more than 400 in neighboring Bexar County). Since 1975, limited professional investigations have concentrated along the Cibolo Creek watershed (Bass and Hester 1975; Kelly and Hester 1976a, 1976b). Amateur investigations in recent years have also been limited to the immediate Cibolo Creek drainage. One recent report of work near the upper Cibolo Creek by Patterson and Adams (1977) documents several campsite-quarry sites.

Aboriginal activities in Kendall County seem to have been centered around open campsites, burned rock middens and the occasional use of rockshelters (Hester 1975). These sites date from the late Paleo-Indian to the Late Prehistoric periods. Most sites are usually located on terraces overlooking drainages. Four major chronological periods are generally recognized for the region: Paleo-Indian (9200-6000 B.C.), Archaic (6000 B.C.-A.D. 500/1000), Late Prehistoric (ca. A.D. 500/1000-1500) and Historic (A.D. 1500+).

\section{FIELD INVESTIGATIONS}

The field work of the Center for Archaeological Research in connection with this project was under the overall supervision of $\mathrm{Dr}$. Thomas R. Hester, Director of the Center, and Mr. Jack D. Eaton, Assistant Director. The archaeological field team consisted of Fred Valdez, Jr., crew chief, and Waynne Cox and A. Joachim McGraw, assistant archaeologists. 
As noted above, Bass and Hester (1975) had identified nine sites, $41 \mathrm{KE} \mathrm{28,}$ $41 \mathrm{KE} \mathrm{40,41} \mathrm{KE} \mathrm{41,} 41 \mathrm{KE} \mathrm{42,41} \mathrm{KE} \mathrm{46,41} \mathrm{KE} \mathrm{54,} 41 \mathrm{KE} 57,41 \mathrm{KE} 58$ and

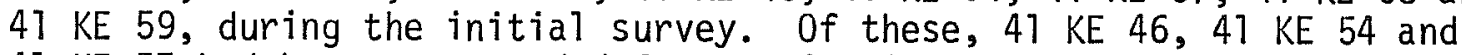
$41 \mathrm{KE} 57$ had been recommended for testing in order to provide a better evaluation of their archaeological potential. All nine sites have been discussed in detail in Bass and Hester (1975). The three tested sites will be described in detail below. Their locations are shown in Fig. 1.

Sites 41 KE 46, 41 KE 54 and 41 KE 57 were revisited by the UTSA field team for testing and re-evaluation. Site $41 \mathrm{KE} \mathrm{54,} \mathrm{a} \mathrm{long,} \mathrm{narrow} \mathrm{site} \mathrm{on} \mathrm{the}$ edge of a terrace, was tested in three locations on a northeast-southwest axis with all excavated material being passed through a 1/4-inch mesh screen. Sites $41 \mathrm{KE} 46$ and $41 \mathrm{KE} 57$ were both tested with units laid out as shown in Figs. 2 and 5 . Here, too, all excavated material was screened through 1/4inch mesh. Test pits were usually one-meter squares, with some testing at $41 \mathrm{KE} 57$ in the form of $50-\mathrm{cm}$ squares. Standard archaeological methods and procedures were used as set forth in Hester, Heizer and Graham (1975). A11 excavated materials were taken to the UTSA Archaeology Laboratory for processing and analysis. Field records are on file at the Center for Archaeological Research office.

\section{RESULTS OF FIELD INVESTIGATIONS}

\section{KE 46}

The site is located on a rocky knoll on the western edge of the large bend at the upper end of Lake $0 z$, roughly $120 \mathrm{~m}$ northwest of site $41 \mathrm{KE} 54$. The site is about $80 \mathrm{~m} \times 120 \mathrm{~m}$ and is roughly rectangular in plan (Bass and Hester 1975:22). Abundant 1ithic materials were scattered on the surface, including chert flakes, points, bifaces, cores and a burned rock accumulation approximately $15 \mathrm{~m}$ in diameter. The general surface collection from the preliminary survey included one stemmed dart point, several biface fragments, preforms and an assortment of primary, secondary and tertiary flakes. Not noted during the earlier survey but perhaps important to its location as a center for aboriginal activity was the site's proximity to a large spring along Frederick Creek.

During the present investigations, seven one-meter squares were excavated to a maximum depth of $40 \mathrm{~cm}$ using arbitrary 10-cm levels (Fig. 2). The excavation units were placed at 10-m intervals along north-south and east-west axes laid out across the site. Most units reached 1 imestone bedrock or sterile caliche within $30 \mathrm{~cm}$. The maximum depth of cultural materials never exceeded $25 \mathrm{~cm}$ and most of the remains were recovered in the upper $15 \mathrm{~cm}$. A detailed description of excavation procedures is on file at the Center.

Cultural materials recovered during the limited excavations consisted of lithic debris and Rabdotus sp. snail shell concentrations. Most prominent among the 1ithic debris were secondary and tertiary flakes (see Table 1), often firereddened and less than $1 \mathrm{~cm}$ in length. No ceramics, bone or diagnostic 
This page has been

redacted because it

contains restricted

information. 


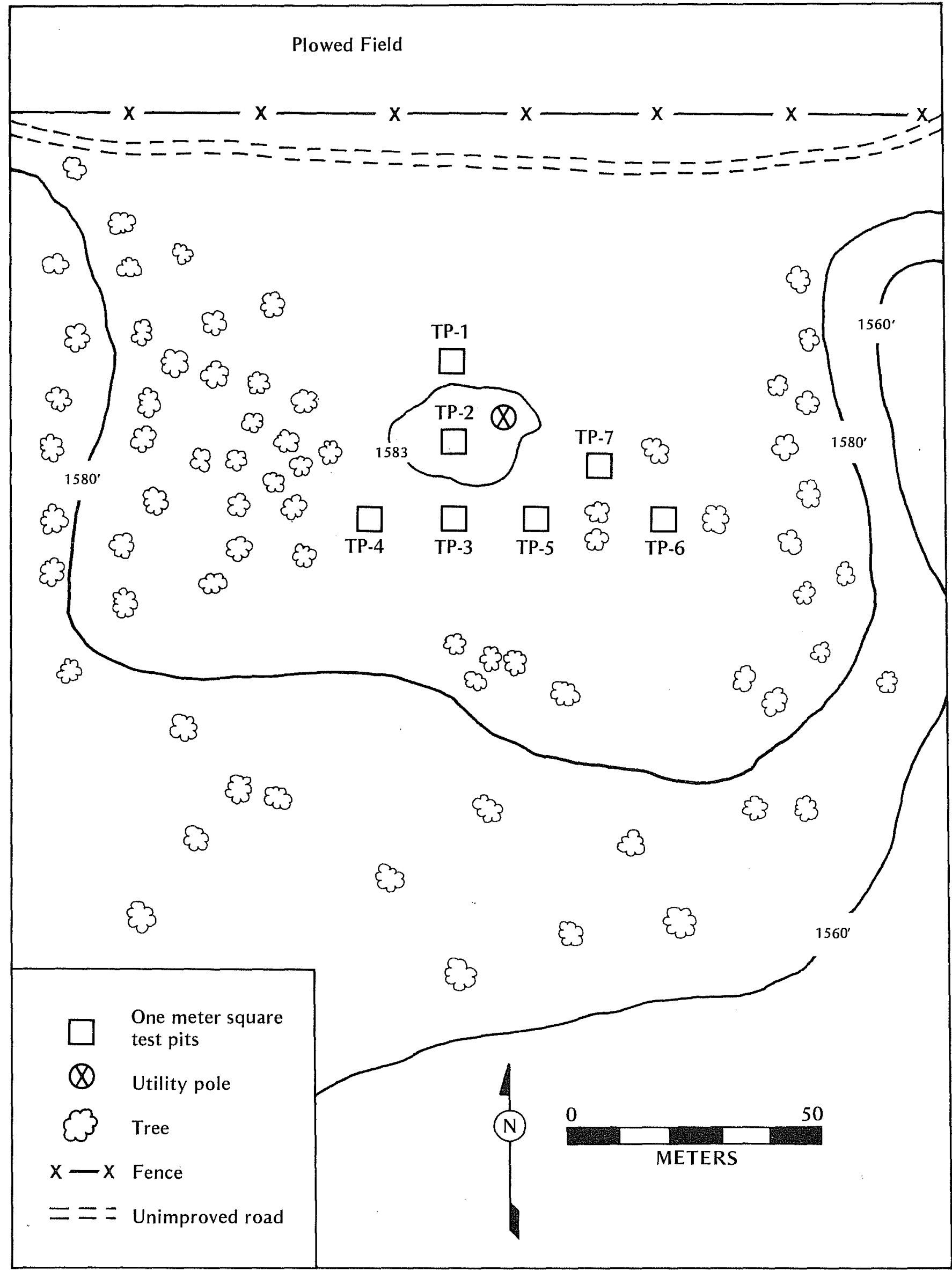

Figure 2. $41 \mathrm{KE}$ 46. Locations of test units are shown. 


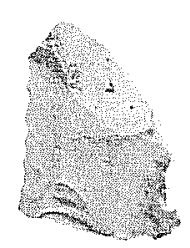

a

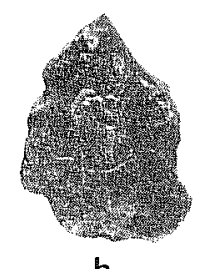

b

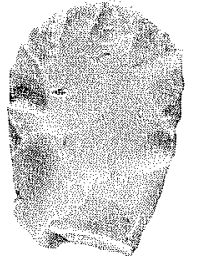

c

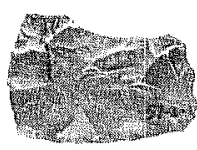

d
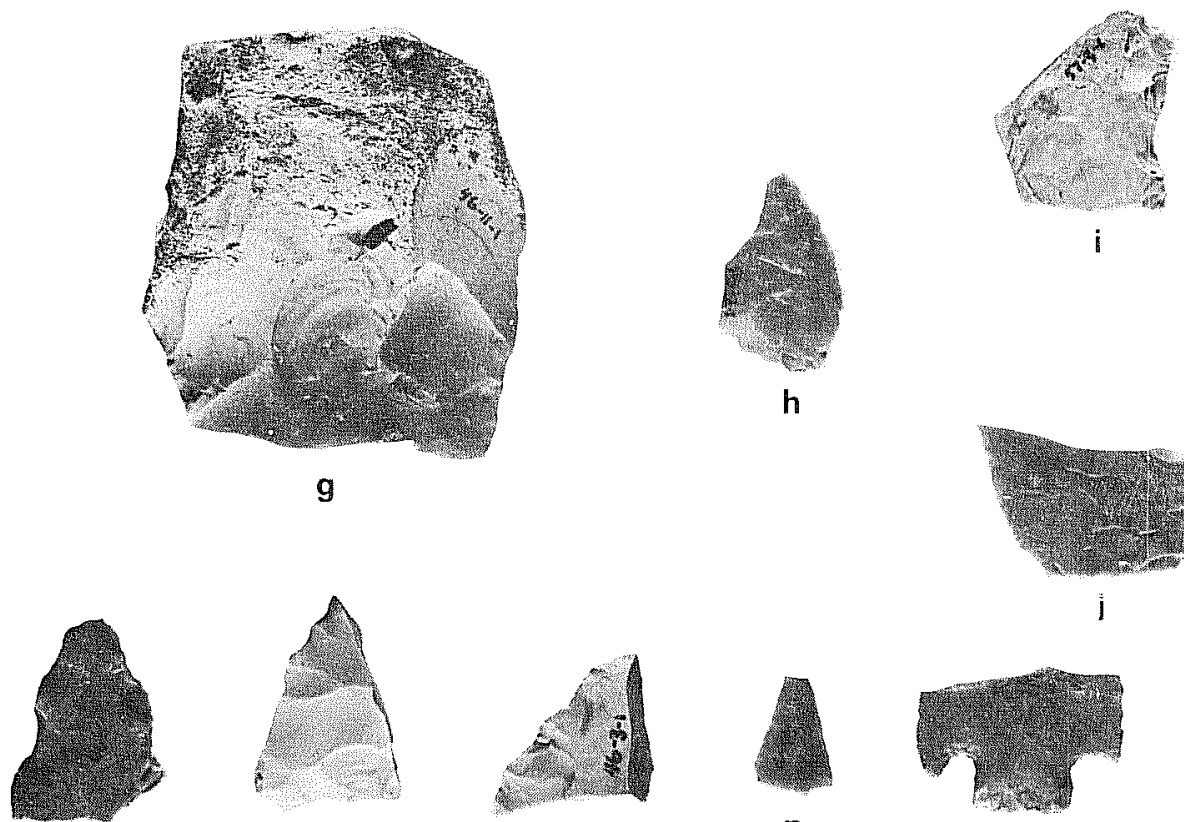

m

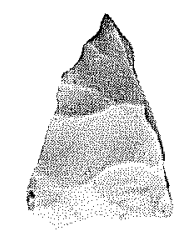

$n$

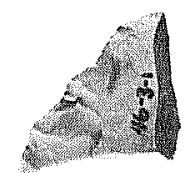

o

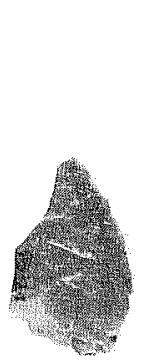

h

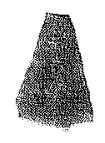

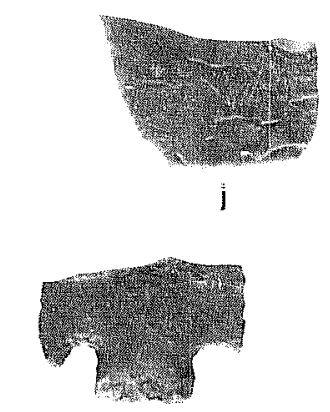

q

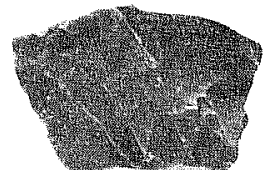

e

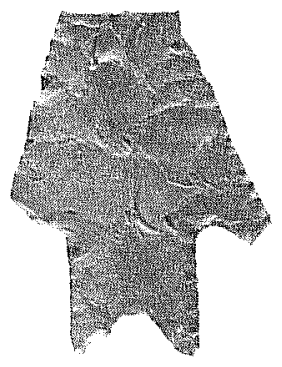

$k$

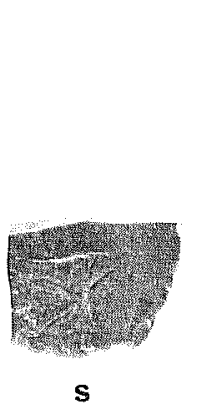

$\mathbf{s}$
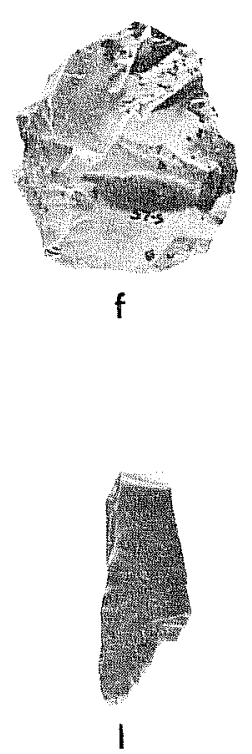

r

Figure 3. Lithic Artifacts. 41 KE 46: a, worked flake; b-c, thin bifaces; g, chopper-1ike biface; h,m-o, crude bifaces; $p$, medial portion of arrow point. $41 \mathrm{KE} \mathrm{57:} \mathrm{d,} \mathrm{basal} \mathrm{section} \mathrm{of} \mathrm{biface;} \mathrm{e,} \mathrm{medial} \mathrm{portion}$ of crude biface; $f$, thin biface fragment; $i$, medial portion of projectile point; $j$, medial portion of thin 
TABLE 1

Provenience of Collected Materials from 41 KE 46

\begin{tabular}{|c|c|c|c|c|c|c|c|c|c|}
\hline $\begin{array}{l}\text { Excavation* } \\
\text { Units/Levels }\end{array}$ & $\begin{array}{l}\mathscr{y} \\
\stackrel{0}{0}\end{array}$ & 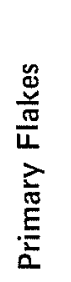 & 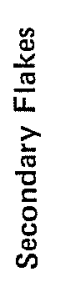 & 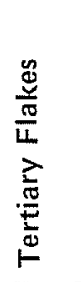 & $\stackrel{\mathscr{2}}{\frac{2}{\bar{c}}}$ & 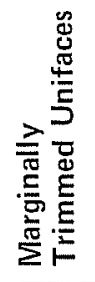 & 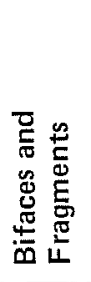 & 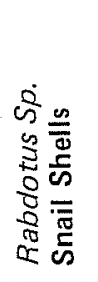 & 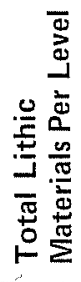 \\
\hline $1-1$ & & 1 & 2 & 5 & 7 & & 1 & & 16 \\
\hline $2-1$ & & & 3 & 13 & 30 & & & 62 & 46 \\
\hline $2-2$ & & 1 & 1 & 5 & 5 & & 1 & 323 & 13 \\
\hline $3-1$ & & 1 & 1 & 9 & 29 & 1 & 2 & & 43 \\
\hline $3-2$ & & & 1 & 1 & & & & & 2 \\
\hline $3-3$ & & & & & 1 & & & & 1 \\
\hline $4-1$ & & & 1 & 11 & & 1 & & & 13 \\
\hline $5-1$ & 1 & 1 & 12 & 36 & 123 & 2 & 1 & & 175 \\
\hline $5-2$ & & & 1 & 1 & 9 & & 2 & & 13 \\
\hline $6-1$ & & 11 & 68 & 241 & 25 & & 2 & & 347 \\
\hline $6-2$ & & 1 & 6 & 21 & 4 & & & & 32 \\
\hline $7-1$ & & 3 & 9 & 39 & 253 & 4 & 3 & & 311 \\
\hline 7.2 & & & & 9 & & & & & 9 \\
\hline TOTALS & 1 & 19 & 105 & 391 & 486 & 8 & 12 & 385 & \\
\hline
\end{tabular}

* Only the units/levels which produced artifacts are listed. 
projectile points were recovered; however, Mr. Julius Gompert, the current property owner, has in his collection several Pedernales dart points and large, thin, finely worked bifaces (averaging $10 \mathrm{~cm}$ in length) which he had previously collected from the site.

Based on excavations and analys is of the recovered artifacts, $41 \mathrm{KE} 46$ appears to have been the site of prehistoric occupation and probably lithic workshop activity (see Table 1). Because of the lack of cultural depth and a scarcity of significant archaeological materials, no further work is recommended at this site.

\section{KE 54}

During the current project this site was tested and re-evaluated to determine its actual extent. Preliminary observations in 1975 suggested the site, located to the north of and adjacent to $41 \mathrm{KE} 46$, was, in all probability, a continuation of that site. Areal measurements were defined as $20 \mathrm{~m} \times 60 \mathrm{~m}$; however, the site appears much larger. Although no surface collection was made at this site in 1975, a limestone metate was noted and recorded.

When the site was revisited in July 1977, the metate recorded earlier was not found. While lithic scatter was evident adjacent to $41 \mathrm{KE} \mathrm{54,} \mathrm{it} \mathrm{was} \mathrm{also}$ noted for another $275 \mathrm{~m}$ or so, downstream along the drainage terrace toward Lake 0z. No diagnostic projectile points were found, although there. was a moderate to heavy scattering of flakes, fire-cracked rocks, and occasionally, a preform or uniface. The extent of the site northward, away from the creek, was not accurately determined due to disturbance from modern-day plowing. Several transects across the plowed field revealed lithic debris scattered as far as $75 \mathrm{~m}$ north of the drainage.

A hearth was noted about $30 \mathrm{~m}$ north of $41 \mathrm{KE} 46$ along the terrace overlooking Frederick Creek. A $1-\mathrm{m}^{2}$ test pit was laid out on top of the hearth and excavated to $25 \mathrm{~cm}$. Only a few (4) tertiary flakes were found on the surface and no cultural debris was noted below the depth of $3 \mathrm{~cm}$. Subsequent to the hearth excavation, two more $1-m^{2}$ test pits were excavated along the terrace at 75-m intervals. During the course of the excavations, it became evident that there was no cultural debris below $5 \mathrm{~cm}$ in any of the test pits. The excavators noted a change in the color, composition and texture of the soil 4 to $5 \mathrm{~cm}$ below the surface. This was noted as a transition from a dark to medium gray clayey loam to a distinctly fine-grained clay-like material. The latter fits the general description of the " $C$ " soil horizon of the Krum soil series of Kenda11 County (SCS personnel, personal communication 1977), usually found about 40 inches below the surface. It is postulated that heavy erosion along the terrace in the past has removed the upper soil horizons and has exposed once-stratified lithic debris.

Because of the shallow depth of cultural deposits and the lack of significant numbers of artifacts, no further work is considered necessary at this site. 
This page has been

redacted because it

contains restricted

information. 
This site lies on the south side of Frederick Creek just east of where an unimproved dirt road crosses the stream. The site is estimated to be about $45 \mathrm{~m}$ in diameter. Flakes and a few biface fragments were noted on the surface. Bulldozing and relic collection have led to considerable destruction at the site. The bulldozer cut two rings around the midden giving it a "doughnut" shape. Because of the severe disturbance of the site it was difficult to place excavation units in undisturbed areas of the midden. The pattern of testing (Fig. 5) led to the placement of some test units next to the bul1dozer track allowing for investigation of this partially disturbed area.

This site has been defined as a burned rock midden (Bass and Hester 1975:23). The problems of burned rock middens, the method of excavations and the function of these sites have been discussed by several authors (Kelley and Campbel1 1942; Kelly 1960; Hester 1970, 1973, 1975; Weir 1976). Two of the three sites tested during the current project (41 KE 46 and 41 KE 57) have burned rock middens on them. As stated by Weir (1976:34), "no sites are more characteristic of central Texas (Archaic) sites" than the burned rock middens. Kendal1 County provides an ideal example of this statement with approximately half of $i$ ts recorded sites listed as burned rock middens (Hester 1975). However, they are highiy variable in form. Perhaps a more appropriate term for some of these sites may be "burned rock accumulations" or "burned rock scatters," depending on size and depth (Gerstle, Kelly and Assad 1977; Weir 1976:40).

In testing $41 \mathrm{KE} 57,1-\mathrm{m}^{2}$ excavation units were placed at 10 m intervals across the site, while $50-\mathrm{cm}^{2}$ units were located $5 \mathrm{~m}$ apart. Excavation of unit 57-1 went to the greatest depth at $60 \mathrm{~cm}$ below the surface, al though cultural material ended at approximately $53 \mathrm{~cm}$. As noted in Table 2, the largest amount of material was located in the upper excavation levels. Fig. 7 shows the relation between chert flakes and land snail shells (Rabdotus sp.) both at the center of the midden and toward the fringe or periphery. It is interesting to note that the number of snail shells is extremely high in relation to chert flakes in the center of the accumulation, while they decrease in the fringe area. The large number of snails occurring toward the center of the midden was concentrated in small clusters. Whether this is a natural occurrence or related to aboriginal activities at this site is still undetermined.

The amount of burned rock, the site's location on a low terrace, and its easy access to the creek might typify the site as a probable food processing station, with occasional campsite activities. So little cultural material was found in or associated with the site that we feel the heavy (or intensive) occupation areas must have been located elsewhere, and this site may have been used for very specialized activities. Fig. 6 provides a detailed profile of the south wall in excavation unit 1 at this site. Only three diagnostic points were located during the excavations and Mr. J. Gompert, an eyewitness to the disturbance of the site, noted that few diagnostic points were found during the bulldozing. 
This page has been

redacted because it

contains restricted

information. 

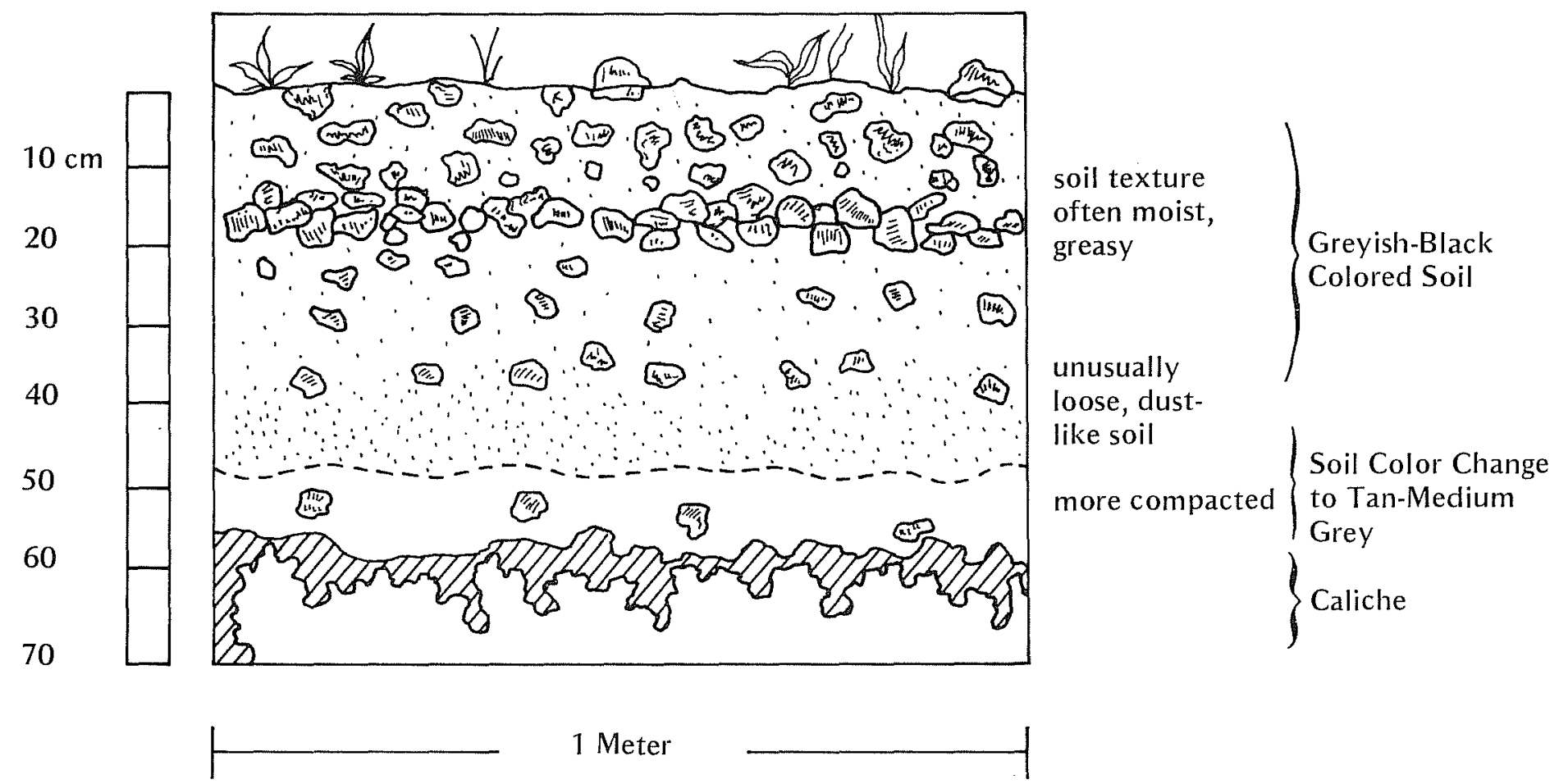

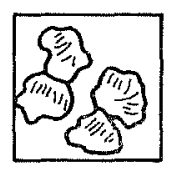

Rubble

Limestone and

Burned Rocks

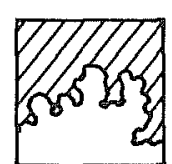

Caliche

Figure 6. 41 KE 57. Profile of south wall of Test Pit 1. 


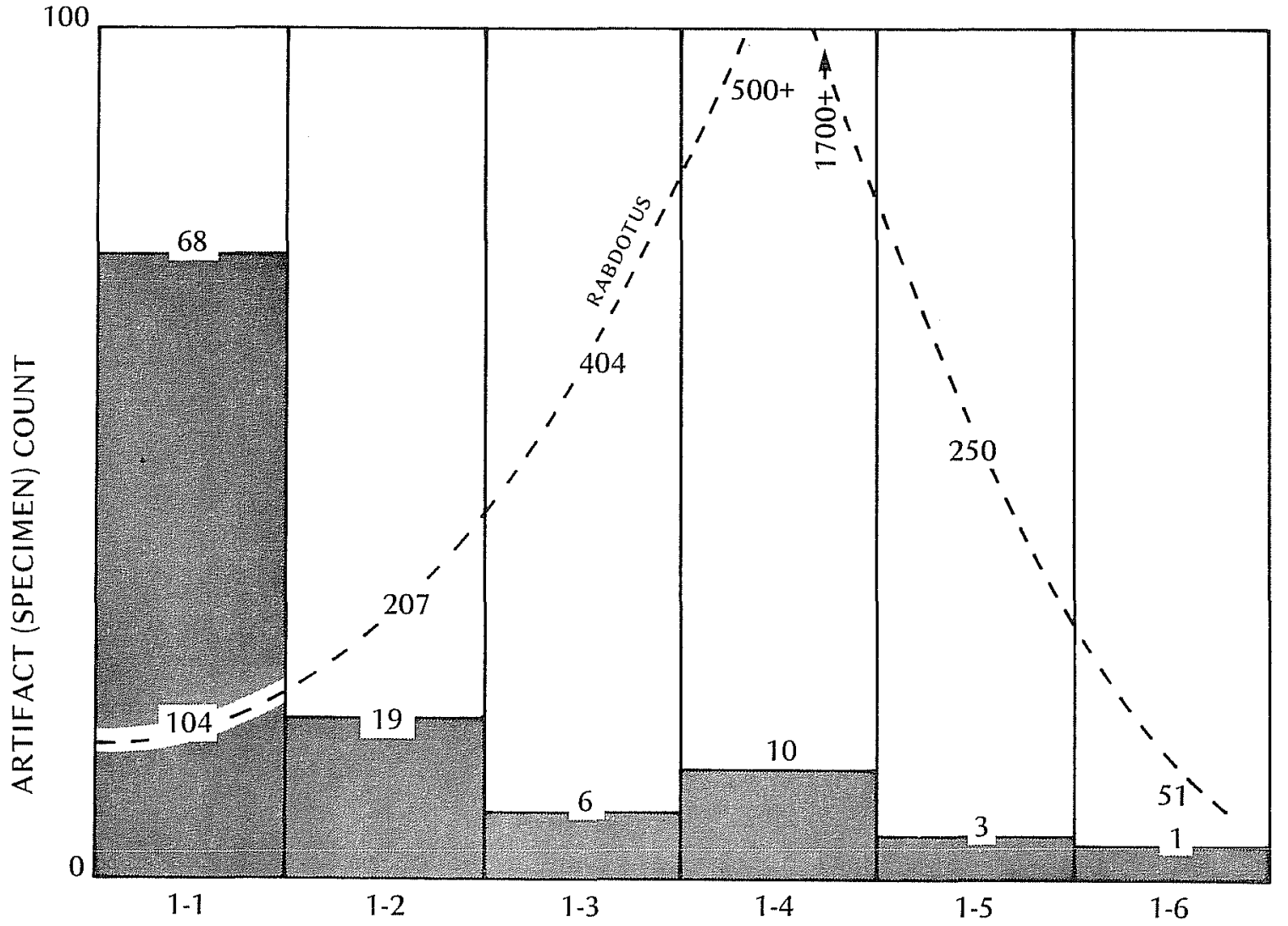

500

425

250

175

5
3
0
0
$\frac{n}{2}$
0
0
$\frac{1}{2}$

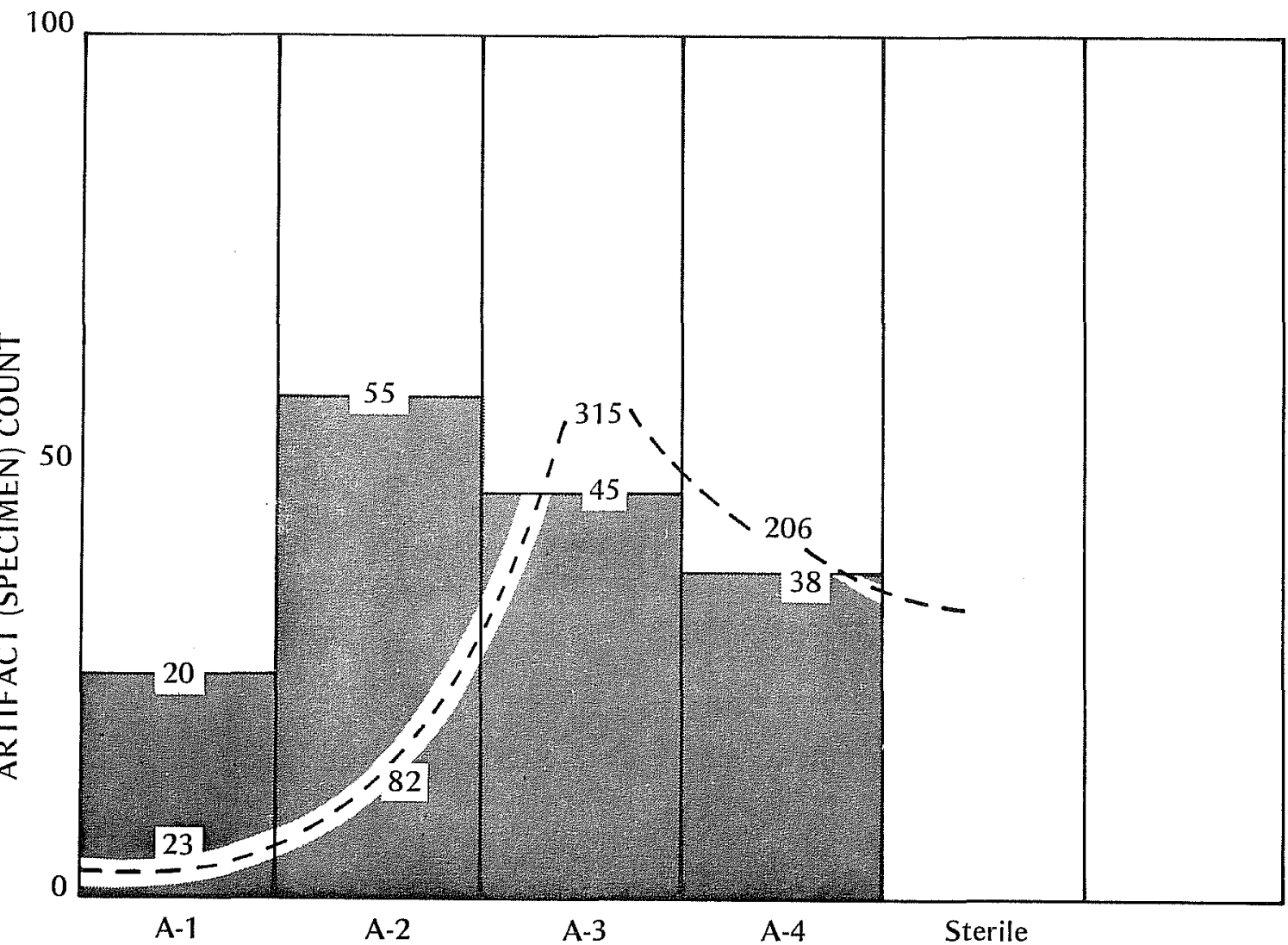

Figure 7. $41 \mathrm{KE}$ 57. Correlation of Rabdotus sp. shell concentrations with total artifact count in Test Pit 1 and Test Pit A. a, Test Pit 1 (center of midden area);
$b$, Test Pit A (fringe area of midden). 
TABLE 2

Provenience of Collected Materials from 41 KE 57

\begin{tabular}{|c|c|c|c|c|c|c|c|c|c|c|c|}
\hline $\begin{array}{l}\text { Excavation * } \\
\text { Units/Levels }\end{array}$ & ⿷匚ّ & $\begin{array}{l}\frac{\infty}{0} \\
\stackrel{0}{0} \\
0 \\
0 \\
\end{array}$ & 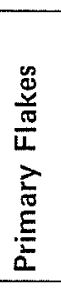 & 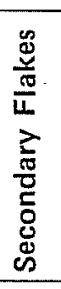 & 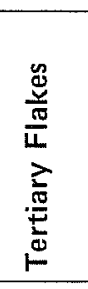 & $\stackrel{n}{\frac{2}{E}}$ & 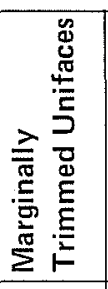 & 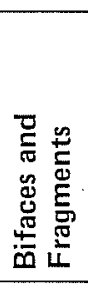 & 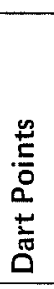 & 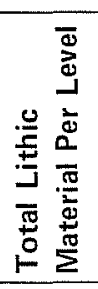 & 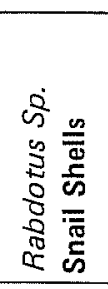 \\
\hline $1-1$ & 1 & & 1 & 6 & 60 & & & & & 68 & 104 \\
\hline $1-2$ & 1 & & 2 & 1 & 15 & & & & & 19 & 207 \\
\hline $1-3$ & & & & 1 & 4 & 1 & & & & 6 & 404 \\
\hline $1-4$ & & & 1 & 1 & 8 & & & & & 10 & +1700 \\
\hline $1-5$ & & & & & 3 & & & & & 3 & 250 \\
\hline $1-6$ & & & & & 1 & & & & & 1 & 51 \\
\hline $2-1$ & & & 1 & 2 & 29 & & & 3 & & 35 & 6 \\
\hline $2-2$ & & & 2 & 1 & 28 & 1 & & & & 32 & 5 \\
\hline $3-1$ & & & 2 & 2 & 37 & 2 & & 2 & & 45 & 4 \\
\hline $4-1$ & & & 2 & 4 & 62 & 3 & & & & 71 & 3 \\
\hline $4-2$ & & & 1 & 5 & 19 & & & & & 25 & 9 \\
\hline $\mathrm{A}-1$ & & & 2 & 1 & 16 & 1 & & & & 20 & 23 \\
\hline A-2 & & & 1 & 5 & 47 & & 1 & & 1 & 55 & 82 \\
\hline$A-\dot{3}$ & & 1 & & 1 & 43 & & & & & 45 & 315 \\
\hline$\dot{\mathrm{A}}-4$ & 1 & & & 5 & 30 & 1 & & & & 37 & 206 \\
\hline B-1 & & & 3 & 5 & 34 & 2 & & & & 44 & 13 \\
\hline C-1 & & & & & 2 & & & & & 2 & \\
\hline D-1 & & & & & 4 & 1 & 3 & & & 8 & \\
\hline$F-1$ & & & & 1 & 7 & & & & & 8 & 15 \\
\hline$F-2$ & & & & & 4 & & & & & 4 & 10 \\
\hline $\mathrm{H}-1$ & & & 2 & 2 & 14 & & & & 1 & 19 & 24 \\
\hline $\mathrm{H}-2$ & & & & & 5 & & & & & 5 & 5 \\
\hline$J-1$ & & & 1 & 2 & 6 & & & & 1 & 10 & 1 \\
\hline$K-1$ & & & 4 & 9 & 100 & 2 & & & & 115 & 24 \\
\hline $\mathrm{K}-2$ & 1 & & 1 & 4 & 21 & 1 & & & & 28 & 14 \\
\hline L-1 & & & & 3 & 3 & 1 & & & 1 & 8 & 32 \\
\hline L-2 & & & & & 2 & 1 & & & & 3 & 12 \\
\hline$L-3$ & & & & & 4 & & & & & 4 & 39 \\
\hline TOTALS & 4 & 1 & 26 & 61 & 608 & 17 & 4 & 5 & 4 & & 3558 \\
\hline
\end{tabular}

* Only the units/levels which produced artifacts are listed. 
Of the four dart point fragments recovered during excavations two have been identified as Pedernales ( $F i g, 3, k, 1$ ), one is a Marshall (Fig. 3, $q$ : Suhm, Krieger and Jelks 1954) and the fourth was unidentified (Fig. 3,r). The three identifiable points were located in the upper $10 \mathrm{~cm}$ of the excavation while the fourth was in the second level at $12 \mathrm{~cm}$. Other biface medial sections or biface fragments discovered during the course of the excavations are presented in Fig. 3. Of the chipped stone debris recovered, interior flakes were overwhelmingly dominant (Table 2). This may be the result of a final stage in the manufacture of tools possibly related to food processing or occasional campsite activities. Chipped stone and debris distributions are shown (by unit and level) in Table 2. A detailed report of excavation procedures and results is on file at the Center for Archaeological Research.

As a result of intensive testing (16 units) and the analysis of artifacts, 41 KE 57 appears to have been a site of limited use for specialized activities. Due to the great amount of disturbance already done at the site and the small amount of significant cultural debris, no further work is recommended at this site.

\section{SUMMARY AND RECOMMENDATIONS}

Testing of three sites on Frederick Creek in Kendall County, Texas, was conducted in July 1977. After redefining the boundaries of the sites and conducting an intensive surface inspection, testing was initiated. The first site tested was $41 \mathrm{KE} 54$, a terrace site. Testing at this site (three units) revealed no cultural material below $5 \mathrm{~cm}$. The probability of much erosion was apparent as a " $C$ " soil horizon was located at depths of $25 \mathrm{~cm}$. Cultural material was limited to a few flakes. $41 \mathrm{KE} 46$ was the second site to be tested and had within its boundaries a partially eroded burned rock accumulation. Seven test pits were excavated at this site, including one unit placed in the center of the burned rock accumulation. All units encountered bedrock or caliche at $30 \mathrm{~cm}$. Cultural deposits did not exceed $25 \mathrm{~cm}$ and most of the material was located above $15 \mathrm{~cm}$. Diagnostic materials were not found at this site during intensive survey or during the testing period. The third site, $41 \mathrm{KE} \mathrm{57,} \mathrm{is} \mathrm{a} \mathrm{burned} \mathrm{rock} \mathrm{accumulation} \mathrm{which} \mathrm{has} \mathrm{been} \mathrm{greatly} \mathrm{disturbed}$ by bulldozing and relic-collecting activities. At 41 KE 57 sixteen units were dug: four $1-\mathrm{m}^{2}$ units and twelve $50 \mathrm{-cm}$ squares. Considering the extent of testing at this site not much significant cultural material was found. The presence of burned limestone and the lack of much artifactual material leads us to suggest that the site was possibly an area for specialized activities (e.g., food processing), as opposed to an intensively or repeatedly occupied zone. Of the four dart points located, two have been identified as Pedernales, and one as Marshall (the fourth was unidentified), indicating use of the area during the Middle Archaic period.

Due to the extent of erosion at site 41 KE 54 and lack of potentially significant cultural material, no further work is recommended. Site $41 \mathrm{KE} 46$ appears to be a very shallow, widespread site with very little cultural deposit and no further work is recommended. The large burned rock accumulation of $41 \mathrm{KE} 57$ also does not need additional work since the site has been extensively damaged and the cultural material collected from this site probably does not present an accurate picture of past activities at the site. 
Although we do not recommend further work on any of these three sites, we do request that an archaeologist be present at site $41 \mathrm{KE} 57$ if it is to be altered during the construction of the proposed floodwater retarding structure. A more detailed study of its profile and contents might be made at that time and would aid in better understanding this site.

\section{REFERENCES CITED}

Bass, Feris $A_{0}$, Jr. and Thomas R. Hester

1975 An Archaeological Survey of the Upper Cibolo Creek Watershed, Central Texas. Center for Archaeological Research. The University of Texas at San Antonio, Archaeological Survey Report 8.

Gerstle, Andrea, Thomas C. Kel1y and Cristi Assad

1977 The Fort Sam Houston Project: An Archaeological and Historical Assessment. Center for Archaeological Research, The University of Texas at San Antonio, Archaeological Survey Report 40.

Hester, Thomas R.

1970 Burned Rock Middens on the Southwestern Edge of the Edwards Plateau, Texas. Plains Anthropologist 15(50):237-250.

1973 The Formation of a "Burned Rock Midden": A California Example. The Record, Dallas Archaeological Society 29(3).

Hester, Thomas R. (assembler)

1975 Archaeological and Historical Resources in the San AntonioGuadalupe River Basins: A Preliminary Statement. Center for Archaeological Research. The University of Texas at San Antonio, Regional Studies 1.

Hester, Thomas R., Robert F. Heizer and John A. Graham

1975 Field Methods in Archaeology. 6th Revised Edition. Mayfield Publishing Company, Paio Aito.

Kelley, J. Charles and T.N. Campbell

1942 What are the Burned Rock Mounds of Texas? American Antiquity $7(3): 379-322$.

Kelly, Thomas C.

1960 The Crumley Site: A Stratified Burnt Rock Midden, Travis County, Texas. Bulletin of the Texas Archeological Society $31: 239-272$. 
Kelly, Thomas C. and Thomas R. Hester

1976a Archaeological Investigations at Sites in the Upper Cibolo Creek Watershed, Centra1 Texas. Center for Archaeological Research. The University of Texas at San Antonio, Archaeological Survey Report 17.

1976b An Archaeological Assessment of Boerne City Park, Kenda11 County, Texas. Center for Archaeological Research. The university of Texas at San Antonio, Archaeological Survey Report 21 .

Patterson, L. W. and H. H. Adams

1977 An Archeological Complex in Kendall County, Texas. La Tierra $4(2): 6-16$.

Suhm, Dee Ann, A. D. Krieger and E. B. Jelks

1954 An Introductory Handbook of Texas Archeology. Bulletin of the Texas Archeological Society 25.

Weir, Frank $A$.

1976 The Central Texas Archaic. Unpublished Doctoral Dissertation. Washington State University. 